\title{
Effect of Irrigation Management and Crop Establishment Methods on Growth, Yield, and Economics of Rice
}

\author{
Shabana ${ }^{1}$, Vinod Kumar, Rajan Kumar*, Alisha Kumari and Sweeti Kumari \\ Department of Agronomy, Dr. Rajendra Prasad Central Agricultural University, \\ Pusa, Samastipur 848125, Bihar, India \\ *Corresponding author
}

Keywords

Grain yield, Irrigation management, Alternate wetting and drying method, Crop establishment methods, Transplanting and direct seeded rice

Article Info

Accepted:

04 March 2019

Available Online:

10 April 2019

\section{A B S T R A C T}

A field experiment was conducted during rainy (kharif) season of 2017 at crop research centre, Pusa, Bihar in split plot design. The treatments consisted of three irrigation management i.e. $\mathrm{I}_{1}$-Continuous submergence throughout crop growth, $\mathrm{I}_{2}$-Saturation maintenance upto PI and $(5 \pm 2 \mathrm{~cm})$ after PI and $\mathrm{I}_{3}$ - Alternate wetting and drying $(5 \mathrm{~cm}$ irrigation at 3 DADPW) upto PI and $(5 \pm 2 \mathrm{~cm})$ after PI in main plot and four methods of establishment i.e. $\mathrm{E}_{1^{-}}$Normal transplanting, $\mathrm{E}_{2^{-}}$Direct wet seeding on puddled soil, $\mathrm{E}_{3^{-}}$ Direct dry seeding and $\mathrm{E}_{4}-$ Broadcasting on un-puddled soil in sub plots. The results of experiments showed that growth and yield attributes like plant height $(117.71 \mathrm{~cm})$, leaf area index (4.26), number of panicles $/ \mathrm{m}^{2}$ (209.61), number of grains/panicle (88.04), grain and straw yields (3722 and $5366 \mathrm{~kg} / \mathrm{ha}$ ), gross returns $(84513 ₹ / \mathrm{ha})$, net returns $(41435$ ₹/ha) and B: C (0.98) ratio were not influenced by irrigation management but water use efficiency $(37.90 \mathrm{~kg} / \mathrm{ha}-\mathrm{cm})$ was found to be maximum with $\mathrm{I}_{3}$ and was significantly superior to $I_{1}$, which was statistically at par with $I_{2}$.With regard to crop establishment methods plant height $(127.81 \mathrm{~cm})$, leaf area index $(4.64)$, panicles $/ \mathrm{m}^{2}(219.12)$, number of grains/panicle (91.44), grain yield $(4053 \mathrm{~kg} / \mathrm{ha})$, straw yield $(5826 \mathrm{~kg} / \mathrm{ha})$, WUE $(44.50$ $\mathrm{kg} / \mathrm{ha}-\mathrm{cm})$, gross returns (91955 ₹/ha) and net returns(47190 ₹/ha) were recorded maximum with $E_{1}$ treatment of crop establishment methods which was significantly superior to $E_{2}, E_{3}$ and $E_{4}$ except, number of panicles $/ \mathrm{m}^{2}$ were statistically at par with $E_{2}$ treatment and $\mathrm{E}_{3}$ while straw yield was statistically at par with $\mathrm{E}_{2}$ treatment. $\mathrm{B}$ : $\mathrm{C}$ ratio (1.06) was not influenced significantly due to different crop establishment methods.

\section{Introduction}

Rice (Oryza sativa L.) is the major source of calories for half the world's population as well as in our country. There are several ways for rice cultivation in the world. The most important cultivation methods are transplanting (TPR) and direct seeding of rice
(DSR). Traditionally rice is cultivated by puddling followed by transplanting which not only leads to wastage of water but is also a costly, cumbersome and time consuming process, induces high bulk density, high soil strength and low permeability in subsurface layer which can restrict root development. It results in degradation of soil and other 
resources (Pathak et al., 2011) and subsequently poses difficulties in seed bed preparation for succeeding crop. Production by this method requires approximately 3000 to 5000 litre of water to produce $1 \mathrm{~kg}$ of rice. The increase in water scarcity and declining rate of per capita fresh water availability along with increasing demand of food has made the present researcher to look for alternate options which increase the water use efficiency (WUE) along with saving of water. Under such situation, DSR is a major opportunity to change production practices to attain optimal plant density and high water productivity in water scarce areas. DSR is the method of sowing seeds directly in the field. There are three principal methods of DSR: dry seeding (sowing dry seeds into dry soil), wet seeding (sowing pre-germinated seeds on wet puddled soils) and water seeding (seeds sown into standing water). In addition to higher economic returns, DSR crops are faster and easier to plant, less labour intensive and consume less water (Bhushan et al., 2007). In non-puddled condition, eliminates the needs of raising, maintaining and subsequent transplanting of seedling. Besides early maturity of crop, it allows timely sowing of subsequent crop too. Also there is urgent need to develop-irrigation water saving techniques as well as proper irrigation schedule that requires less irrigation input than the traditional method, which also increase production and productivity of rice crop. Alternate wetting and drying (AWD) irrigation is water saving technique in rice production and is an important adaptation strategy under climate change where water scarcity may become more prevalent. Under AWD, fields are subjected to intermittent flooding (alternate cycles of saturated and unsaturated conditions) where irrigation is interrupted and water is allowed to subside until the soil reaches a certain moisture level, after which the field is again flooded. Keeping in view of the above mentioned prospects, the present investigation entitled "Effect of irrigation management and crop establishment methods on performance of rice" has been conducted to assess the performance of irrigation management and crop establishment methods on growth and yield of rice with higher WUE.

\section{Materials and Methods}

A field experiment was conducted during kharif season of 2017 in split plot design with three replications at Crop Research Centre, Dr. Rajendra Prasad Central Agricultural University, Pusa, Bihar, situated in Samastipur district of North Bihar on the Southern and Western bank of the river Burhi Gandak at $25^{\circ} 59^{\prime}$ North latitude and $85^{\circ} 48^{\prime}$ East longitude with an altitude of 52.92 meters above mean sea level. It has subtropical and sub humid monsoon climate. The average rainfall of the area is $1276.1 \mathrm{~mm}$ out of which nearly $1026.0 \mathrm{~mm}$ is received during the monsoon between June and September. The treatments consisted of three irrigation management i.e. $\mathrm{I}_{1}$-Continuous submergence throughout crop growth, $\mathrm{I}_{2}$-Saturation maintenance upto PI and $(5 \pm 2 \mathrm{~cm})$ after PI and $\mathrm{I}_{3^{-}}$Alternate wetting and drying $(5 \mathrm{~cm}$ irrigation at 3 DADPW) upto PI and $(5 \pm 2 \mathrm{~cm})$ after PI in main plot treatments and four methods of establishment i.e. $\mathrm{E}_{1}$ - Normal transplanting, $\mathrm{E}_{2^{-}}$Direct wet seeding on puddled soil, $\mathrm{E}_{3}$ - Direct dry seeding and $\mathrm{E}_{4}{ }^{-}$ Broadcasting on un-puddled soil in sub plots. The test cultivar was Abhishek.

The soil of experimental plot was sandy loam in texture, alkaline in reaction ( $\mathrm{pH}-8.5)$, low in available $\mathrm{N} \quad 154 \mathrm{~kg} / \mathrm{ha}$ (Alkaline permanganate method, Subbiah and Asija, 1956), $\mathrm{P}_{2} \mathrm{O}_{5} 19.21 \mathrm{~kg} / \mathrm{ha}$ (Olsen's method, Olsen et al., 1954) and $\mathrm{K}_{2} \mathrm{O} 121.00 \mathrm{~kg} / \mathrm{ha}$ (Flame photometer method, Jackson, 1967). The crop was fertilized with 120:60:40:25 $\mathrm{kg} / \mathrm{ha} \mathrm{N}-\mathrm{P}_{2} \mathrm{O}_{5}-\mathrm{K}_{2} \mathrm{O}-\mathrm{ZnSO}_{4}$. Application of half 
(50\%) dose of nitrogen and total phosphorus and potash and $\mathrm{ZnSO}_{4}$ were applied as basal and remaining dose of nitrogen in two equal splits $(25 \% \mathrm{~N}$ at active tillering and $25 \% \mathrm{~N}$ at panicle initiation stage).irrigation was applied as per treatments. The amount of irrigation applied was measured through Parshall flume. The total input of water was the sum of irrigation water and effective rainfall occurred during the crop growing period. WUE is the expression of the marketable product (grain) obtained by per unit of water applied to the crop. It can be determined with the help of the following formula:

\section{Water use efficiency $(\mathrm{kg} / \mathrm{ha}-\mathrm{cm})=$ Yield (kg/ha) \\ Water requirement $(\mathrm{cm})$}

No incidence of diseases and pests occurred during the crop season. However, Follidol dust was applied before flowering to prevent rice gundhi bug attack. The crop was harvested when the leaves turned into yellow to brown. The crop was harvested in morning hours when there was enough overnight dew to avoid the loss of grain shattering. Harvesting was done manually with the help of sickles. Before harvesting sample plants were taken separately from $1 \mathrm{~m}^{2}$ and tagged for postharvest studies.

To eliminate the border effect, two rows from all the four sides of the plot harvested separately as border rows. Threshing and winnowing of grains were done manually and yield of sun dried grains were recorded approximately at 14 per cent moisture.

\section{Results and Discussion}

\section{Growth and yield attributing parameters}

Growth and yield attributing parameters vary non-significantly under various moisture regimes and significantly in Crop establishment method as shown in Table 1.

\section{Plant height}

Plant height at harvest showed non-significant difference with continuous submergence throughout crop growth, Saturation maintenance upto PI and $(5 \pm 2 \mathrm{~cm})$ after PI and Alternate wetting and drying $(5 \mathrm{~cm}$ irrigation at 3 DADPW) upto PI and $(5 \pm 2 \mathrm{~cm})$ after PI. It was due to adequate supply of water maintained good establishment of root and various metabolic processes that performed better nutrient mobilization at all the three irrigation management treatments. It was in conformity with the result of Kumar et al., (2015). The maximum plant height (127. 81 $\mathrm{cm})$ was recorded at harvest with normal transplanting which was significantly superior to direct wet seeding on puddled soil direct dry seeding and broadcasting on un-puddled soil. This might be due to plants were specific distance in normal transplanting and the competition between the plants were minimum and deep penetration of roots resulting in efficient use of nutrient uptake and flooding providing good condition for germination as well as for growth.

\section{Leaf area index}

A critical examination of the data revealed that the LAI did not vary significantly due to different irrigation management practices. This was due to adequate supply of moisture which favored more number of large sizes leaves at all the irrigation management treatments. Similar result was also noticed by Kumar et al., (2015). Different crop establishment methods significantly influenced LAI. The maximum LAI (4.64) was observed at 90 DAS with normal transplanting which was significantly superior to direct wet seeding on puddled soil, direct dry seeding and broadcasting on un-puddled soil. This might be due to the facts that plants were at specific distance in normal transplanting and the competition between the 
plants were minimum thus, crop enjoyed favourable conditions with respect to light, space and nutrients etc. Similar view was expressed by Sharma et al., (2016).

\section{Number of panicles $/ \mathrm{m}^{2}$}

Irrigation management did not exert significant influence on number of panicles $/ \mathrm{m}^{2}$ viz., continuous submergence throughout crop growth, Saturation maintenance upto PI and $(5 \pm 2 \mathrm{~cm})$ after PIand alternate wetting and drying $(5 \mathrm{~cm}$ irrigation at 3 DADPW) upto PI and $(5 \pm 2 \mathrm{~cm})$ after PI. These results were supported by Kadiyala et al., (2012) and Kumar et al., (2015). In sub plot treatments, Crop establishment methods caused a significant variation on number of panicles $/ \mathrm{m}^{2}$. The highest panicles $/ \mathrm{m}^{2}$ $\left(219.12 / \mathrm{m}^{2}\right)$ was observed with normal transplanting, which was statistically at par with direct wet seeding on puddled soil, direct dry seeding and significantly superior to broadcasting on un-puddled soil. This might be due to unavailability of proper plant spacing in case of broadcasting on un-puddled soil. This result was in close conformity to Sahu et al., (2015).

\section{Number of grains/ panicle}

Number of grains/panicle depends on the efficient translocation of photosynthates from source to sink. Higher the translocation of photosynthates higher will be the number of grains per panicle. The effect of irrigation management on number of grains/panicle was found to be non-significant. This might be due to efficient translocation through continuous supply of water in all the irrigation management treatments. The results are in close conformity to those given by Ramakrishna et al., (2007). While in sub plot treatments regarding different crop establishment methods there was significant effect. The highest grains/panicle (91.44/panicle) was observed with normal transplanting which was significantly superior to rest of the treatments. This might be due to fertility of spikelets and development of grains depend on environmental factors such as nutrient, moisture and light, wider spacing in normal transplanting possibly facilitated to supply the more food materials, moisture and light for the plant and ultimately developed panicle length and grains/panicle. This result was in close conformity to Sahu et al., (2015).

\section{Yield, Water use efficiency, Economics}

Yield, Economics vary non significantly and Water use efficiency vary significantly under different moisture regimes while in Crop establishment method all vary significantly except B: $\mathrm{C}$ ratio as shown in Table 2.

\section{Grain yield}

Different irrigation managements did not influence significantly the grain yield of rice. Grain yield obtained with continuous submergence throughout crop growth recorded maximum value (37.22 $\mathrm{q} / \mathrm{ha})$ which was closely followed by saturation maintenance upto PI and $(5 \pm 2 \mathrm{~cm})$ after PI and alternate wetting and drying $(5 \mathrm{~cm}$ irrigation at 3 DADPW) upto PI and $(5 \pm 2 \mathrm{~cm})$ after PI. This might be due to the grain yield of a crop is the combined effect of various growth and development parameters. In the present investigation, almost all the growth and development characters seemed to be unaffected by different irrigation management treatments. These finding were collaborated with the results of Dhar et al., (2008), Kumar et al., (2015) and Sathish et al., (2017).Different crop establishment methods exerted a significant effect on grain yield. The maximum grain yield $(40.53 \mathrm{q} / \mathrm{ha})$ was recorded with normal transplanting, which was significantly superior to direct wet seeding on puddled soil, direct dry seeding 
and broadcasting on un-puddled soil because the planting distance ensure air circulation, water and light which are basic factors necessary for photosynthesis. Further proper spacing increases tillers and grain yield. Similar results were obtained by Anbumani et al., (2004) and Sahu et al., (2015).

\section{Straw yield}

Straw yield of rice was not affected significantly by irrigation management. This was due to non-significant effect increase in plant height, LAI and number of tillers $/ \mathrm{m}^{2}$. Similar finding were reported by Kumar et al., (2015). Analyzed mean data on straw yield was significantly affected by crop establishment methods. Higher straw yield (58.26 q/ha) was associated with normal transplanting which was statistically at par with direct wet seeding on puddled soil and significantly superior to direct dry seeding and broadcasting on un-puddled soil due to greater dry matter production per unit area, caused by better nutrient absorption from the soil, and the increased rate of metabolic processes, rate of light absorption and photosynthetic activity as well as more number of leaves under normal transplanting. Parameshwari and Srinivas (2014) also reported the similar result.

\section{Water use efficiency}

Water use efficiency was significantly influenced due to different irrigation managements. However, maximum value of WUE was recorded with alternate wetting and drying ( $5 \mathrm{~cm}$ irrigation at 3 DADPW) upto PI and $(5 \pm 2 \mathrm{~cm})$ after PI $(37.90 \mathrm{~kg} / \mathrm{ha}-\mathrm{cm})$ which was statistically at par with saturation maintenance upto PI and $(5 \pm 2 \mathrm{~cm})$ after PI and was significantly superior to continuous submergence throughout crop growth. This might be due to higher yield of grain with lower water use at alternate wetting and drying ( $5 \mathrm{~cm}$ irrigation at 3 DADPW) upto PI and $(5 \pm 2 \mathrm{~cm})$ after PI and saturation maintenance upto PI and $(5 \pm 2 \mathrm{~cm})$ after PI caused higher water use efficiency in comparison to continuous water stagnant treatment. This finding was confirmed by Fonteh et al., (2013). The water use efficiency with regard to different levels of crop establishment methods was found to be significant. The maximum water use efficiency was recorded with normal transplanting $(44.50 \mathrm{~kg} / \mathrm{ha}-\mathrm{cm})$ which was significantly superior to direct wet seeding on puddled soil, direct dry seeding and broadcasting on un-puddled soil. This might be due to the reason that WUE is directly proportional to economic yield and due to higher yield in normal transplanting.

\section{Economics}

Gross returns are the directive of total biological (grain + straw) yield of any crop. In case of irrigation management; it did not significantly influence gross returns of rice. In case of crop establishment methods, maximum gross returns was recorded with normal transplanting (91955 ₹/ha) which was significantly superior to direct wet seeding on puddled soil, direct dry seeding and broadcasting on un-puddled soil. This is due to higher grain and straw yield obtained from normal transplanting. Similar trend was observed by Sanjay et al., (2006), Jnanesha and Ashish (2017) and Kumar and Batra (2017).

Net returns were not influenced significantly by different irrigation managements. The maximum net returns recorded with continuous submergence throughout crop growth due to higher gross returns followed by alternate wetting and drying $(5 \mathrm{~cm}$ irrigation at 3 DADPW) upto PI and $(5 \pm 2 \mathrm{~cm})$ after PI and saturation maintenance upto PI and $(5 \pm 2 \mathrm{~cm})$ after PI. 
Table.1 Effect of moisture regimes and crop establishment methods on growth and yield attributing characters of rice

\begin{tabular}{|c|c|c|c|c|}
\hline Treatments & $\begin{array}{c}\text { Plant height }(\mathbf{c m}) \\
\text { at harvest }\end{array}$ & $\begin{array}{l}\text { Leaf area index } \\
90 \text { DAS }\end{array}$ & $\begin{array}{l}\text { Number of } \\
\text { panicles } / \mathbf{m}^{2}\end{array}$ & $\begin{array}{c}\text { Number of grains/ } \\
\text { Panicle }\end{array}$ \\
\hline \multicolumn{5}{|c|}{ Irrigation management } \\
\hline $\mathbf{I}_{1}$ & 117.71 & 4.26 & 209.61 & 88.04 \\
\hline $\mathbf{I}_{2}$ & 109.63 & 3.95 & 205.89 & 83.31 \\
\hline $\mathbf{I}_{3}$ & 107.27 & 3.85 & 203.66 & 82.18 \\
\hline SEm \pm & 2.70 & 0.09 & 3.66 & 1.94 \\
\hline $\mathrm{CD}(\mathrm{P}=0.05)$ & NS & NS & NS & NS \\
\hline \multicolumn{5}{|l|}{$\begin{array}{l}\text { Crop establishment } \\
\text { method }\end{array}$} \\
\hline $\mathbf{E}_{1}$ & 127.81 & 4.64 & 219.12 & 91.44 \\
\hline $\mathbf{E}_{2}$ & 111.39 & 4.01 & 207.11 & 84.11 \\
\hline $\mathbf{E}_{3}$ & 109.46 & 3.93 & 204.95 & 83.60 \\
\hline $\mathbf{E}_{4}$ & 97.48 & 3.49 & 194.37 & 78.89 \\
\hline SEm \pm & 5.23 & 0.13 & 5.15 & 2.43 \\
\hline $\mathrm{CD}(\mathrm{P}=\mathbf{0 . 0 5})$ & 15.54 & 0.39 & 15.30 & 7.22 \\
\hline
\end{tabular}

$\mathrm{I}_{1}$-Continuous submergence throughout crop growth, $\mathrm{I}_{2}$-Saturation maintenance upto PI and $(5 \pm 2 \mathrm{~cm})$ after PI , $\mathrm{I}_{3}$-Alternate wetting and drying (5 $\mathrm{cm}$ irrigation at 3 DADPW) upto PI and $(5 \pm 2 \mathrm{~cm})$ after PI , $\mathrm{E}_{1}-$ Normal transplanting, $\mathrm{E}_{2}$ - Direct wet seeding on puddled soil , $\mathrm{E}_{3}-\mathrm{Direct}_{\mathrm{r}}$ dry seeding , $\mathrm{E}_{4}$ - Broadcasting on un-puddled soil 
Table.2 Effect of moisture regimes and crop establishment methods on yield, Water use efficiency, and economics of rice

\begin{tabular}{|c|c|c|c|c|c|c|}
\hline Treatments & $\begin{array}{l}\text { Grain yield } \\
\text { (kg/ha) }\end{array}$ & $\begin{array}{c}\text { Straw yield } \\
\text { (kg/ha) }\end{array}$ & $\begin{array}{l}\text { Water use } \\
\text { efficiency } \\
\text { (kg/ha-cm) }\end{array}$ & $\begin{array}{c}\text { Gross } \\
\text { returns } \\
\text { (₹/ha) }\end{array}$ & $\begin{array}{l}\text { Net returns } \\
(₹ / h a)\end{array}$ & $\begin{array}{l}\mathrm{B}: \mathrm{C} \\
\text { ratio }\end{array}$ \\
\hline \multicolumn{7}{|c|}{ Irrigation management } \\
\hline $\mathbf{I}_{1}$ & 3722 & 5366 & 32.26 & 84513 & 41435 & 0.96 \\
\hline $\mathbf{I}_{2}$ & 3453 & 4997 & 35.03 & 78512 & 38934 & 0.98 \\
\hline $\mathbf{I}_{3}$ & 3365 & 4889 & 37.90 & 76604 & 39027 & 1.04 \\
\hline SEm \pm & 78 & 158 & 0.89 & 1995 & 1995 & 0.05 \\
\hline $\mathrm{CD}(\mathrm{P}=\mathbf{0 . 0 5})$ & NS & NS & 3.51 & NS & NS & NS \\
\hline \multicolumn{7}{|c|}{ Crop establishment method } \\
\hline $\mathbf{E}_{1}$ & 4053 & 5826 & 44.50 & 91955 & 47190 & 1.06 \\
\hline $\mathbf{E}_{2}$ & 3509 & 5077 & 29.80 & 79774 & 37279 & 0.88 \\
\hline $\mathbf{E}_{3}$ & 3438 & 4989 & 34.92 & 78233 & 40938 & 1.10 \\
\hline $\mathbf{E}_{4}$ & 3053 & 4443 & 31.04 & 69543 & 33788 & 0.95 \\
\hline SEm \pm & 114 & 259 & 1.18 & 3051 & 3051 & 0.08 \\
\hline $\mathrm{CD}(\mathrm{P}=0.05)$ & 339 & 769 & 3.51 & 9065 & 9065 & NS \\
\hline
\end{tabular}

$\mathrm{I}_{1}$-Continuous submergence throughout crop growth, $\mathrm{I}_{2}$-Saturation maintenance upto PI and $(5 \pm 2 \mathrm{~cm})$ after PI , $\mathrm{I}_{3}$-Alternate wetting and drying (5 $\mathrm{cm}$ irrigation at $3 \mathrm{DADPW})$ upto PI and $(5 \pm 2 \mathrm{~cm})$ after PI, $\mathrm{E}_{1}-$ Normal transplanting, $\mathrm{E}_{2}$ - Direct wet seeding on puddled soil , $\mathrm{E}_{3}-$ Direct dry seeding , $\mathrm{E}_{4}$ - Broadcasting on un-puddled soil 
Similar result was found by Balasubramanian and Krishnarajan (2001). There was significant influence of different crop establishment methods on net returns. The maximum net returns was recorded with normal transplanting (47190 ₹/ha) which was significantly superior to direct wet seeding on puddled soil and broadcasting on un-puddled soil but was statistically at par with direct dry seeding. This was due to maximum gross returns and cost of cultivation. These finding were in agreement with Sanjay et al., (2006). Irrigation management did not significantly influence the B: $\mathrm{C}$ ratio. The maximum B: C ratio (1.04) was recorded with alternate wetting and drying $(5 \mathrm{~cm}$ irrigation at 3 DADPW) upto PI and $(5 \pm 2 \mathrm{~cm})$ after PI and minimum with continuous submergence throughout crop growth. This was due less requirement of irrigation and hence less cost of cultivation in case of alternate wetting and drying condition and more in continuous submergence condition. These finding were in agreement with Nayak et al., (2016). In crop establishment methods, different treatments of it did not significantly influenced the B: C ratio. The maximum $\mathrm{B}$ : $\mathrm{C}$ ratio was recorded with direct dry seeding (1.10) and minimum with direct wet seeding on puddled soil (0.88).This might be due to saving in labour and water resulted in decreasing in cost of cultivation as well as increasing net returns in DSR condition. This result is in accordance with finding of Gangwar et al., (2008) and Jnanesha and Ashish (2017).

\section{References}

Anbumani, S., Chandrasekharan, B. and Kuppuswamy, G. 2004. Evaluation of establishment methods and NPK levels in rice and their impact on succeeding crops. Agricultural Science Digest 24(3): 190-193.

Balasubramanian, R. and Krishnarajan, J. 2001. Yield and correlation studies in direct seeded rice as influenced by irrigation levels. Indian Journal of Agricultural Research 35(3): 194-197.

Bhushan, L., Ladha, J.K., Gupta, R.K., Singh, S., Tirol-Padre, A., Saharawat, Y.S., Gathala, M. and Pathak, H. 2007. Saving of water and labor in a ricewheat system with no-tillage and direct seeding technologies. Agronomy Journal 99(5): 1288-1296.

Dhar, R., Gupta, N. K. and Samanta, A. 2008. Effect of irrigation scheduling on the performance of kharif rice grown under different establishment methods. Journal of Research, SKUAST-J7(2): 277-280.

Fonteh, M.F., Tabi, F.O., Wariba, A.M. and Zie, J. 2013. Effective water management practices in irrigated rice to ensure food security and mitigate climate change in a tropical climate. Agriculture and Biology Journal of North America 4(3): 284-290.

Gangwar, K. S., Gill, M. S., Tomar, O. K. and Pandey, D. K. 2008. Effect of crop establishment methods on growth, productivity and soil fertility of ricebased cropping system. Indian Journal of Agronomy 53(2): 102-106.

Jackson, M. L. 1967. Soil Chemical Analysis, Prentice Hall of India Pvt. Ltd., New Delhi: 498.

Jnanesha, A. C. and Kumar, A. 2017. Effect of crop establishment methods on growth yield and water productivity of rice. International Journal on Agricultural Sciences 8(1): 4045.

Kadiyala, M. D. M., Mylavarapu, R.S., Li, Y. C., Reddy, G. B. and Reddy, M. D. 2012. Impact of aerobic rice cultivation on growth, yield and water productivity of rice-maize rotation in semi-arid tropics. Agronomy Journal 104(6): 1757-1765.

Kumar, R. and Batra, S.C. 2017. A Comparative Analysis of DSR 
Technology Vs. Transplanted Method in Haryana. Economic Affairs 62(1): 169-174.

Kumar, R., Das, S., Kumar, V., Dwivedi, D.K. and Das, L. 2015. Studies on irrigation and weed management for enhancing rice yield and water productivity under system of rice intensification. The Bioscan 10(1): 417420.

Nayak, B.R., Pramanik, K., Khanda, C.M., Panigrahy, N., Samant, P.K., Mohapatra, S., Mohanty, A.K., Dash, A.K., Panda, N. and Swain, S.K. 2016. Response of aerobic rice (Oryza sativa L.) to different irrigation regimes and nitrogen levels in western odisha. Indian Journal of Agronomy 61(3): 321325.

Olsen, S.R., Cole, C.U., Watanable, F.S. and Dean, L.A. 1954. Estimation of available phosphate in soils by extraction with $\mathrm{NaHCO}_{3}$. USDA Circular: 939.

Parameswari, Y.S. and Srinivas, A. 2014. Influence of weed management practices on nutrient uptake and productivity of rice under different methods of crop establishment. Journal of Rice Research 7: (1\&2).

Pathak, H., Tewari, A.N., Sankhyan, S., Dubey, D.S., Mina, U., Singh, V.K., Jain, N. and Bhatia, A. 2011. Directseeded rice: Potential, performance and problems- A review. Current Advances in Agricultural Sciences 3(2): 77-88.

Ramakrishna, Y., Singh, S. and Parihar, S. S.
2007. Influence of irrigation regime and nitrogen management on productivity, nitrogen uptake and water use by rice (Oryza sativa). Indian Journal of Agronomy 52: 102-106.

Sahu, R., Singh, M.K. and Yadav, L. 2015. Yield and economics as influenced by nitrogen scheduling, weed management and rice establishment methods in transplanted rice (Oryza sativa). Indian Journal of Agronomy 60(2): 261-266.

Sanjay, M. T., Prabhakara, T. K. and Nanjappa, H. V. 2006. Soil test crop response approach in rice (Oryza sativa L.) under different methods of crop establishment. Crop Research 31: 346349.

Sathish, A., Kumar, K. A., Reddy, P. R. R., and Devi, M. U. 2017. Effect of different crop establishment methods and irrigation regimes on rice (Oryza sativa L.) Yield and Water Use Efficiency. International journal of Current Microbiology and Applied Sciences 6(9): 90-95.

Sharma, V., Bali, A.S. and Kachroo, D. 2016. Effect of different establishment methods and sowing schedules on growth and yield of hybrid rice (Oryza sativa) and their after effects on succeeding wheat (Triticum aestivum) in rice -wheat cropping system. Economic Affairs 61(3): 487-493.

Subbiah, B.V. and Asija, G. L. 1956. A rapid procedure for assessment of available nitrogen in rice soil. Current Science 31: 196.

\section{How to cite this article:}

Shabana, Vinod Kumar, Rajan Kumar, Alisha Kumari and Sweeti Kumari. 2019. Effect of Irrigation Management and Crop Establishment Methods on Growth, Yield, and Economics of Rice. Int.J.Curr.Microbiol.App.Sci. 8(04): 443-451. doi: https://doi.org/10.20546/ijcmas.2019.804.048 